\title{
CHOCOLAT E VÊNUS NEGRA: CORPO, IDENTIDADE E MEMÓRIA
}

\author{
Catarina Andrade
}

\begin{abstract}
RESUMO
Este artigo analisa os possíveis desdobramentos discursivos em torno da representação do corpo feminino no cinema a partir de Chocolat (Claire Denis, 1988) e Vênus negra (Abdellatif Kechiche, 2010); tendo em vista esse corpo enquanto objeto de desejo, lugar de resistência, fronteira cultural e étnica, ou mesmo enquanto vestígio de história e memória. Por meio de articulações teóricas, estéticas e políticas sobre essas imagens, e da análise desses filmes, buscaremos entender de que forma o cinema intercultural - capaz de criar novas imagens a partir da memória dos sentidos, pois possui qualidades táteis e contagiantes, com as quais o espectador se confronta como se estivesse se relacionado com um outro corpo (Marks, 2000) - se faz dispositivo de representação de uma possível história cultural e memória, precisamente por meio do papel que os corpos, deslocados de suas paisagens de origem, atuam para a construção dessa história e memória culturais.
\end{abstract}

\section{PALAVRAS-ChAVE}

Cinema; corpo; interculturalidade; memória; pós-colonialismo; representação

\section{ChOCOLAT AND BLACK VENUS: BODY, IDENTITY AND MEMORY}

\begin{abstract}
This article analyses the possible discursive developments around the female body in movies, using Chocolat (Claire Denis, 1998) and Black Venus (Abdellatif Kechiche, 2010); bearing in mind this body as an object of desire, a space of resistance, a cultural and ethnical frontier, or even as a vestige of history and memory. Through theoretical, esthetical and political articulations about these images, and through the analysis of these films, we will attempt to understand how intercultural cinema - which is able to create new images from the memory of the senses, since it possesses tactile and contagious qualities, with which the spectator is confronted as if he was connecting with another body (Marks, 2000) - becomes an instrument of representation of a possible cultural history and memory, precisely by means of the role that bodies - removed from their original environment - play in the construction of this cultural history and memory.
\end{abstract}

\section{KEYWORDS}

Cinema; body; interculturality; memory; post-colonialism; representation 


\section{CHOCOLAT E VÊNUS NEGRA: CORPO, IDENTIDADE E MEMÓRIA}

Tanto Chocolat quanto Vênus negra são filmes construídos a partir de um flashback?. Enquanto no primeiro temos um flashback centrado nas lembranças da personagem principal, France, a partir de um retorno à África, onde vivera com seus pais a infância - lembranças que coincidem com as da própria Claire Denis, dando ao filme um forte caráter autobiográfico -, no segundo, observamos um flashback de caráter mais histórico, que, embora biográfico - e de uma maneira bem mais evidente, com dados concretos sobre a vida de Saartije Baartman -, não desponta das lembranças da personagem central, mas de uma memória coletiva. Para Laura Marks (2000) é uma característica do cinema intercultural a utilização de histórias individuais que, na verdade, estão servindo para representar histórias coletivas. Portanto, queremos compreender as histórias de Saartije e de France como imagens capazes de complementar, dar continuidade, completar em algum nível, a recomposição das histórias de dominação e colonialismo que as precedem e que, provavelmente, as sucederão.

É importante distinguir o ponto de vista a partir do qual pensamos essas imagens. Claramente, não é uma questão de qual imagem é "verdadeira", mas de qual tem uma representação mais persistente, e qual representação possui uma continuidade maior com a camada de imagens que a precederam (Marks, 2000, p. 41). Em Chocolat, France, adulta, depois de ter tido a experiência de viver na França - e de ser Outro na França, de maneira distinta da que era Outro nos Camarões -, recompõe imagens da colonização africana e das relações estabelecidas entre colonizadores e colonizados, a partir do olhar de uma francesa, Claire Denis, que compartilha com France essas memórias. No filme de Kechiche, a memória é uma releitura de fatos históricos da mesma colonização, atentando para uma falsa emancipação - uma vez que Saartije é uma mulher livre e que, a partir do princípio do livre-arbítrio, decide ir com seu patrão, enquanto sócia, realizar apresentações de variedades na Inglaterra -, segundo o olhar de um cineasta beur que partilha, ao menos coletivamente, dessas memórias históricas.

É necessário reconhecer, e isso se torna evidente nesses filmes, que "'o mito do Ocidente' e o 'mito do Oriente' formam duas faces do mesmo signo colonial" (Stam \& Shohat, 2006, p. 40). A certeza desse vínculo inseparável promove a inexorável, porém evidentemente ultrapassada no pensamento crítico, dualidade que gera os sujeitos que se antagonizam: o Eu e o Outro. Desse modo, nos interessam à análise dessas imagens os conceitos de raça e racismo, pois, de acordo com Robert Stam e Ella Shohat, o racismo é um discurso e também uma prática:

o racismo é a tentativa de estigmatizar a diferença com o propósito de justificar vantagens injustas ou abuso de poder (...); não é todo grupo que detém

\footnotetext{
' Russel Kilbourn (2010) desenvolve seu pensamento acerca do cinema enquanto um dispositivo de memória e compreende o flashback como um recurso de representação da memória dentro do universo cinematográfico. Assim, muitas vezes - flashback é motivado pelo enredo quando um personagem busca, através da memória, fatos e acontecimentos do seu passado, de um passado que lhe foi contado, ou até mesmo de um passado coletivo ou histórico. Nesse sentido, oflashback se produz num espaço-tempo próprio da memória de determinado personagem (ou de vários personagens), sendo esse espaço-tempo sempre distinto do espaço-tempo do enredo do filme.
} 
o poder necessário para praticar o racismo, ou seja, para traduzir uma atitude preconceituosa em opressão social. (Stam \& Shohat, 2006, p. 51)

Consequentemente, as causas do racismo são ao mesmo tempo econômicas, psicológicas e discursivas, manifestando-se em cada um desses campos de maneiras distintas, porém complementares. Stuart Hall (2003) elabora também uma discussão importante a respeito dos termos "raça" e "etnia", demonstrando como o discurso em torno dessas categorias está relacionado ao multiculturalismo do século XX e como é apropriado social e politicamente. Hall afirma que o racismo opera, dentro da prática discursiva, por meio de uma lógica própria, uma vez que se valida do que não é próprio ao termo "raça", que é exatamente o caráter científico, biológico, natural. Assim, ainda na primeira metade do século XX, as distinções raciais existiam, sobretudo, para justificar as relações de dominação (material e simbólica), ou seja, justificavam as hierarquias sociais que sustentavam os grupos dominantes.

\section{Cinema e RepresentaÇão}

Para pensarmos a representação desses personagens no cinema, marcados pela história da discriminação racial, é necessário admitir, ainda que minimamente, que as "raças" existem nos imaginários e que, de alguma maneira, conseguiram sobreviver à sua invalidação científica. Ou seja, a "raça" é uma categoria imaginária construída historicamente, assim como as noções de nação ou de gênero (Ndiaye, 2008, p. 33), reforçando, assim, uma categoria válida de análise social, dotada do sentido que lhe atribuíram as circunstâncias sociopolíticas.

Para Ndiaye, assim como para Hall, uma outra possibilidade identitária se funda na menção de uma origem étnica. Diferentemente da "raça", a etnia dificilmente pode ser reconhecida - mesmo que superficialmente - num primeiro contato visual. Por outro lado, o racismo também se revelará em diversos registros das combinações identitárias baseadas na etnia. Um franco-senegalês, por exemplo, pode ter sua identidade questionada por não 'parecer' francês, ou seja, embora tenha nascido na França e se autorreconheça como francês, sua identidade é constantemente investigada por parecer haver algum tipo de contradição. O inverso evidentemente também acontece. É o caso, por exemplo, de Manuel, personagem do filme Chocolat, filho de Marie Vial, nascido na África, de pais franceses, que, por possuir a pele e os cabelos claros, não só é tratado como estrangeiro - e há outros fatores que reforçam essa atitude, como veremos mais adiante -, como esses traços são considerados pelos africanos negros como mau presságio.

As características que marcam a etnicidade, transmitidas culturalmente, associam-se às biológicas, transmitidas geneticamente, atravessando gerações. Dessa forma, os discursos de "raça" e "etnia" se mesclam - sem se confundirem, entretanto -, estando ambos presentes um no outro e gerando certas associações que, inúmeras vezes, servirão de suporte ao discurso racista. Os discursos da distinção biológica e cultural, na maioria das vezes, operam conjuntamente. Assim, concordamos que o "racismo" e a 
"diferença cultural" são, na verdade, "duas lógicas" (Stam \& Shohat, 2006, p. 71), que se autossustentam numa operação cumulativa.

Tanto no filme Vênus negra como em Chocolat, percebemos que a representação dos personagens passa por essas questões relativas à identidade, inclusive, em muitos momentos, trazendo-as para o campo cinematográfico a partir de personagens que questionam sua própria identidade na tentativa de construir, ou idealizar, uma identidade escolhida.

\section{VÊNUS NEGRA: O CORPO E A MEMÓRIA PÓS-COLONIAL}

A personagem central de Vênus negra, Saartije Baartman (Yahima Torres), uma jovem hotentote que vai para a Europa com seu antigo senhor (que agora se diz seu sócio) na tentativa de ganhar a vida com apresentações em teatro, demonstra, ao longo do filme, questionar sua identidade, ao subverter, por exemplo, certas atitudes que chegam a chocar os que estão ao seu redor e esperam dela determinado comportamento.

Kechiche parece dividir seu longo filme (2h 43min) em três fases, diretamente ligadas à visão que Saartije tem de si mesma e do mundo (sobretudo do mundo europeu): sua chegada à Inglaterra e exibição em teatros decadentes de espetáculos de variedades; sua ida para a França e as apresentações em salons libertins de Paris, após sua independência ter sido questionada em julgamento na corte; o fim dos espetáculos e a vida na prostituição, culminando, enfim, com o seu corpo sendo estudado por um comitê científico (em troca de dinheiro) e com a morte em consequência de doenças. Em todas essas fases, Kechiche faz uso de elementos visuais e estéticos no intuito de promover uma dimensão de crítica e denúncia, questionando o espectador e seus limites, ao ponto do intolerável, em face do horror humano, como também questionando a própria sociedade e sua capacidade de discriminar e estigmatizar a diferença.

Baseado em acontecimentos históricos do início do século XIX, o filme inicia com um flashback: uma exibição da escultura do corpo de Saartije (já morta) em uma aula de anatomia, na Academia Real de Medicina, no ano de 1815. Contudo, por trás do interesse de estudar o corpo de um ser humano, está a tentativa de concluir que não se trata de um ser humano, mas de uma raça de símio. Professores e alunos muito concentrados observam o corpo da mulher hotentote, assim como de sua vulva e vagina, extirpadas e conservadas em formol. Todo o discurso de Cuvier, célebre cientista do início do século $X I X^{2}$, versa na tentativa de comprovar que Saartije não é uma pessoa, não pertence à raça humana, ou seja, na tentativa de determinar não apenas uma identidade que a distancie da europeia, mas uma raça que possa distingui-la dos humanos.

No início do século XIX, as teses do atraso, degeneração e desigualdade orientais em relação ao Ocidente associavam-se muito facilmente a ideias sobre as bases biológicas da desigualdade racial. As classificações

\footnotetext{
${ }^{2}$ A obra Zoos humains et exhibitions coloniales, editada em 2002, evoca esses estudos antropológicos que ocorreram ao longo do século XIX e contribuíram para uma classificação da humanidade em termos de raça, validando, assim, o projeto colonial e as pretensões hegemônicas.
} 
encontradas em Le règne animal, de Cuvier, Essai sur l'inégalité des races humaines, de Gobineau, e The dark races of man, de Robert Knox, encontravam um parceiro solícito no Orientalismo latente. (Said, 2007, p. 280)

Kechiche se vale de várias tomadas em primeiro plano, tanto da estátua do corpo de Saartije, como dos professores e alunos, numa tentativa de aproximar o espectador do campo da consciência dos personagens. Há uma forte tensão mental na cena. À medida que a câmera, lentamente, vai revelando os rostos, vão se revelando as angústias e as incertezas, provocando um desconforto - sobretudo para os espectadores do século XXI. Ao mostrar insistentemente o órgão genital de Saartije, o filme nos introduz desde o primeiro momento ao desejo de denúncia de Kechiche, a denúncia do obsceno, para além da conotação sexual, que vai da Academia Real de Medicina às ruas de prostituição de Paris. A partir desse estudo fragmentado do corpo de Saartije, o cineasta contrapõe e, ao mesmo tempo, aproxima, os racismos que se configuram tanto nas bases culturais quanto nas biológicas.

Após esta cena inquietante, o filme nos leva ao ano da chegada de Saartije à Europa. Com o sonho de ser artista, cantora e dançarina, a jovem exibe seu corpo enjaulado num teatro de rua em Londres. São diversos espetáculos de variedades, homem que cospe fogo, que parte corrente, que doma terríveis feras, acrobatas, e "uma fêmea selvagem do continente africano" (Vénus negra, 2010). Seu sócio, Caezar (Andre Jacobs), descendente de europeu, mas nascido na África, está vestido de domador e anuncia ao público londrino uma fera selvagem que, segundo conta, ele mesmo capturou na floresta africana. A jaula está coberta por uma pele de onça e ele ameaça tirá-la para que todos vejam esta mulher africana selvagem. Mais uma vez, e ao longo de todo o filme, Kechiche fará uso do primeiro plano, aproximando o espectador, fazendo-o, como diz Jean Epstein, penetrar na cena: "entre o espetáculo e o espectador, nenhuma ribalta. Não contemplamos a vida, penetramo-la. Essa penetração permite todas as intimidades" (citado em Martin, 2013, p. 41). Para Mrabet, o uso dessa câmera muito aproximada permite ao cineasta estar o mais perto possível do seu personagem e possibilita ao espectador uma visão "humana" e dolorosa da Vênus (Mrabet, 2014, p. 128).

Dentro da jaula, Saartije se encontra apoiada com os braços no chão, ou bem próximos dele, ou seja, em posição referente aos animais, em contraposição à postura vertical, ereta, referente aos seres humanos. Em nenhum momento, em nenhuma dessas apresentações, Saartije aparece completamente ereta para o público. A longa duração dessas encenações, associada a essa postura, desconfortável para um ser humano, enfatiza o sofrimento e a dor de Saartije, que emigra para a Europa na tentativa de uma vida melhor, na esperança de ser artista, mas a condição racial que lhe é imposta, ratificada pelo discurso colonialista, a mantém, embora longe de sua terra (colonial), na mesma condição de opressão.

As apresentações dos dois têm o tom das encenações de circo. Ele incita o público a gritar. Todos estão ansiosos para ver a "fera": homens, mulheres e até mesmo crianças. Ao descobrir a jaula, vemos uma negra das ancas muito largas e das coxas muito 
grossas. Ela começa a dançar e a cantar. Encorajados pelo "domador", os espectadores gritam sempre mais. Um retrato triste e profundo do colonialismo, a desumanização tanto dos colonizados quanto dos colonizadores provocada por esse sistema. O europeu que domina o africano. Este, por sua vez, negro, portando poucas roupas, comunicando-se em dialeto, oprimido pelo chicote e pela sua própria incapacidade de agir no sistema do dominante. Diante do desconhecido (uma vez que nem mesmo reconhecem Saartije enquanto ser humano), as emoções do público oscilam, indo do estranhamento ao medo.

Essa história da Vênus negra retrata, e denuncia, evidentemente, um momento importante, que tem início entre o final do século XVIII e o início do século XIX, quando os "povos exóticos", os "selvagens", migravam para a Europa para se tornarem atração em espetáculos de exibição.

Africanos e asiáticos foram exibidos como figuras humanas aparentadas com espécies de animais específicas; tomavam-se ao pé da letra, desse modo, as expressões "nativo" e "animal" - em si mesmas subjugadoras, colonialistas e elípticas -, sendo que a própria exibição de pessoas enjauladas já sugeria que se tratava de indivíduos aquém do patamar humano. (Stam \& Shohat, 2006, p. 156)

Esses espetáculos, como podemos ver no filme, eram frequentados até mesmo por crianças e jovens. A imagem canônica do europeu tornava-se a contrapartida para a marginalização de tudo o que não lhe fosse análogo. Dessa forma, Kechiche nos convida a revisitar essa história de opressão na qual se respaldou toda uma política de hegemonia branca e racial, fundamentada em argumentos científicos e pretensamente lógicos. Porém, como afirmou Kechiche em entrevista: "eu não contei a história de Saartije para incriminar a época passada, mas para melhor compreender o presente" (citado em Mrabet, 2014, pp. 126-127).

Num determinado momento da apresentação, Caezar pede que a Vênus desfile como uma "dama europeia", apenas com a intenção de fazer a plateia rir pelo modo de andar desengonçado - um ato encenado por Saartije, que, obviamente, caminha como qualquer outra mulher quando não está no palco -, que a distância de qualquer possibilidade de ser reconhecida como humana ou, ainda, como mulher. $O$ final das apresentações é marcado por um clímax, momento em que a Vênus, de costas para a plateia, mostra as nádegas, que são apalpadas, beliscadas, raramente alisadas, pelo ávido público. As pessoas entram em uma espécie de êxtase quando tocam, beliscam, alisam o corpo de Saartije. Ela, por outro lado, sente-se violentada, às vezes reagindo com pequenos gestos que são repreendidos por Caezar. No rosto de Saartije, que o público não vê, estão presentes a tristeza, a decepção e a dor.

Percebem-se nitidamente a curiosidade e o desejo pelo que é diferente, pelo que é o Outro e, ao mesmo tempo, o receio, o medo. Quer-se possuir e dominar o Outro, mas com a segurança de não se surpreender, de não ser molestado e de sair ileso dessa experiência de contato. Por isso o domador está lá, para mediar essa convivência, para 
torná-la segura. Esta cena parece não ter fim, não apenas pelos seus longos planos, mas também pelos sentimentos que a câmera de Kechiche percorre: a tristeza de Saartije, o entusiasmo de Caezar, o medo e o desejo do público. Em vários momentos, a câmera nos fornece um panorama de 360 graus e vemos palco e plateia compartilhando a violenta cena onde os dominantes exaltam a subjugação dos dominados.

Pensando um pouco nas reflexões do filósofo Slavoj Žižek (2009, p. 56) sobre a violência, observa-se que o medo pelo que é externo ao "eu" é construído social e politicamente com a finalidade, dentre outras, de erguer fronteiras imaginárias, mas extremamente respeitadas, raramente ultrapassadas, entre os diversos povos, num nível global, ou entre as distintas classes, num nível local - percebe-se, por exemplo, neste filme, que tanto o público londrino quanto a africana "permanecem" no "lugar" que lhes é reservado pela sociedade, eles agem exatamente como se espera deles.

E é em torno dessas fronteiras entre os povos que Kechiche constrói seu enredo. O discurso do professor e cientista e o julgamento de Saartije em um tribunal inglês são cenas cuidadosamente construídas para reforçar o poder do discurso eurocêntrico. A partir desse julgamento, Kechiche aborda a questão central do filme, que é a da dignidade humana. No processo, um duplo questionamento se impõe: Saartije consente sua situação ou Saartije está encenando? (Mrabet, 2014, p. 128).

Esse julgamento é fundamental no filme. Através dele, Kechiche lança o questionamento sobre os limites da realidade e da encenação, os limites do verdadeiro e do falso. É interessante observar que, no Tribunal, Saartije não fala por si mesma, mas por meio de um tradutor. Pelo próprio desejo de permanecer na Europa e de tornar-se uma artista - e a incapacidade de perceber que esse sonho é inalcançável -, Saartije reafirma o discurso de Caezar, que se defende argumentando que o público está confundindo representação com realidade. Diante das acusações dos membros da liga africana de exploração humana e atentado contra a dignidade, Caezar responde que Saartije é livre, que ela tem um contrato e recebe um salário.

Contudo, Kechiche nos lança para essa armadilha na qual Saartije está presa e, se, por um lado, vemos uma mulher, vestida como as europeias, reivindicando seu espaço de artista junto a Caezar, por outro, sabemos que ela se submete às regras de Caezar, que não concorda com diversos aspectos das suas apresentações, que sua integridade física e emocional está, sim, ameaçada: "eles podem ver, mas sem tocar; eu não sou uma meretriz; não foi como você prometeu" (Vénus negra, 2010), diz ela a Caezar nos bastidores de uma das performances. Embora o julgamento seja positivo para Caezar, a repercussão do caso o incomoda e surge a possibilidade de se unir a Réaux para promover espetáculos na França.

Assim, o filme passa para o que entendemos como uma segunda fase, delimitada pelo batismo de Saartije, que ganha o nome católico de Sarah, e as apresentações nos salons libertins de Paris. Réaux está acompanhado de Jeanne, uma prostituta que embarca nessa viagem com Saartije e Caezar. Embora Caezar tivesse afirmado na corte que Saartije é uma mulher livre, ele recebe dinheiro de Réaux para mostrar as genitálias da Vênus. Na França, as performances se transformam um pouco. No lugar de uma roupa 
cor da pele, Saartije utiliza uma roupa vermelha, ainda bem aderente ao corpo, que deve ser evidenciado. Além disso, há a presença de Jeanne, que reforça a oposição entre Saartije e as mulheres europeias; um corpo negro, 'selvagem', 'deformado', em contraste com os corpos brancos e vestidos.

O ambiente também se modifica, os decadentes teatros de variedades dão lugar a luxuosos salões, onde as pessoas estão bem vestidas e bebem champanhe. Contudo, os repetitivos planos-sequência de Kechiche reiteram o sofrimento e as angústias vividos pela personagem que, nesta fase, ainda mais do que na anterior, é usada pelos 'sócios', por Jeanne, por homens e mulheres presentes nas apresentações, como objeto sexual; "tocá-la as torna férteis" (Vénus negra, 2010), diz Jeanne durante a performance, referindo-se aos genitais de Saartije. Réaux convida os presentes a montar e a domar a Vênus, antes de estimulá-los a tocar sua genitália. Assim, Kechiche nos confronta com o intolerável da natureza humana, pois, como afirma Mrabet, o filme revela uma mise-en-scène da humilhação de Saartije que leva as plateias de seus espetáculos ao divertimento, ou seja, a mise-en-scène da humilhação é a própria fonte de prazer.

Outro fato significativo nesta fase em Paris é a presença de um jornalista que quer fazer uma entrevista com Saartije. Embora seja uma cena bem curta, dentro de uma carruagem, ela reforça a ideia que o Ocidente faz do Oriente e de seus habitantes. A história de Saartije - que ela conta ao jornalista - destoa da história que ele imaginara. Ele se surpreende quando ela diz que trabalhava na casa da família de Caezar: "você não é uma princesa, é uma empregada!" (Vénus negra, 2010), lamenta ele. Então ele continua a tentar resgatar algum fato na história da Vênus que seja consonante ao discurso do Ocidente sobre o Oriente, perguntando-Ihe se sua família fora dizimada ou massacrada pelos brancos, ao que ela responde que não. Sendo assim, não lhe resta mais do que arrematar: "posso escrever que você foi uma princesa? Vai parecer mais bonito para as leitoras" (Vénus negra, 2010). Visivelmente cansada e abatida, Saartije sinaliza que sim com a cabeça.

A sensualidade, a promessa, o terror, o sublime, o prazer idílico, a energia intensa: o Oriente como uma figura na imaginação orientalista pré-românica e pré-técnica da Europa no final do século XVIII tinha realmente uma qualidade camaleônica chamada (adjetivamente) de "oriental". (Said, 2007, p. 173)

A terceira fase do filme é assinalada pela presença do comitê científico que quer examinar Saartije, pelo fim dos espetáculos e a consequente chegada da personagem a uma casa de prostituição. A partir desse momento do filme, Kechiche vai conduzindo o espectador ao fim de Saartije, à sua morte. Alcóolatra, ela apresenta um rosto cada vez mais triste, mais cansado e desesperançoso. Saartije é vendida por Caezar a Réaux, com assinatura e contrato, o que, mais uma vez, evidencia a divergência entre o discurso e os fatos. Em uma das suas últimas apresentações, o público se incomoda com a violência com que Réaux trata a Vênus: "ela está chorando; não tem mais graça; deixe-a em paz". Réaux responde ao público dizendo que "são lágrimas de alegria e prazer" (Vénus negra, 
2010). Se, em alguns momentos do espetáculo, Saartije podia controlar (e ter algum prazer com) o seu próprio corpo, a partir do fim das apresentações este corpo feminino, negro e africano, é reduzido a objeto de curiosidade, de sexo, de prazer e da ciência.

No contato com o comitê científico, Saartijje é submetida às piores humilhações (Mrabet, 2014, p. 128). Ela é observada e analisada à sua revelia, tratada como um animal. Dentre os cientistas, destacamos a presença de um que contrasta com a violência dos outros personagens no filme, pois, ao pintar Saartije, no jardim do instituto, ele devolve-lhe um pouco de feminilidade, beleza e, sobretudo, de humanidade. Com a morte de Saartije ${ }^{3}$, vítima de sífilis, nas ruas de Paris, Réaux procura o comitê científico, para quem vende o corpo da jovem. Cuvier, finalmente, poderá ver e atestar o "avental hotentote", os genitais da Vênus, que ela não havia mostrado sob nenhuma hipótese ao comitê. O filme, assim, vai fechando seu ciclo, voltando ao lugar onde começou. Kechiche questiona o papel da ciência, sem dúvida imprescindível para os discursos da raça, em seu sentido hierárquico de inferioridade e superioridade.

Em todos os seus filmes, Kechiche busca evidenciar de alguma forma a brutalidade da realidade social e as questões ligadas à dignidade humana, porém, em Vênus negra, esse discurso fica ainda mais evidente por se tratar de um acontecimento histórico, real, e pela força das imagens que ele nos impõe. Se, no início do filme, Saartije é apresentada como um animal enjaulado diante do público de Caezar, é utilizada nos salons libertins como objeto de excitação sexual, o campo científico, não tão surpreendentemente, a tratará de ambas as maneiras. Ele não reconhecerá sua humanidade e a reduzirá em definitivo - graças à "capacidade comprobatória" da ciência - ao que ela sempre foi para os europeus.

Está clara no filme a tentativa do Ocidente de validar, através da ciência, o discurso da distinção das raças em superiores e inferiores e de tentar disseminá-lo como "verdade universal". Como se sabe, no (in)consciente coletivo, o termo oriental (africanos, asiáticos) sempre remeteu a ideias como mulheres sensuais e insaciáveis, exotismo, tendências ao despotismo, desconhecimento da cultura erudita, reduzida capacidade intelectual, atraso, misticismo, alegoria, terrorismo, etc. Para o Ocidente, se o oriental faz parte de uma raça subjugada, como em muitos momentos alguns cientistas tentaram demonstrar (o que também é abordado no filme), ele, o oriental, também deve ser subjugado (Said, 2007, p. 281).

Enquanto retiram os genitais, o cérebro e outros órgãos de Saartije, reconstroem um modelo da Vênus em gesso. Kechiche passa dos detalhes dessa reconstituição aos da destruição do corpo da jovem pelos cientistas. A construção de uma imagem. A Vênus que se quer, que talvez tivesse sido princesa... Essa cena silenciosa e longa revela, mais uma vez, os gestos precavidos e cuidadosos do cientista que havia pintado Saartije e que, novamente, contrasta com a violência dos demais. Esse pequeno prólogo pós-morte se encerra com a cena de abertura do filme no anfiteatro. Kechiche parece querer

${ }^{3}$ Saartije Baartman, nascida em 1789 na África do Sul, morre em 1815, aos 26 anos, em Paris. Até 1974 (159 anos após sua morte), os restos de Saartije foram exibidos em Paris, no Museu de História Natural. Apenas em 1994, a pedido de Nelson Mandela, seus restos foram devolvidos ao seu país, sendo enterrado, contudo, no ano de 2002 (quase dois séculos depois de morta). 
expressar, com esse ciclo, que não se pode, ou pelo menos não se deve, isolar o passado do presente.

\section{CHOCOLAT: IDENTIDADE E MEMÓRIA NA PAISAGEM COLONIAL}

Nesse sentido, também podemos pensar a respeito do filme Chocolat, de Claire Denis. Com um caráter fortemente autobiográfico, Chocolat une passado e presente tanto nas lembranças da memória do personagem principal, France (Mireille Perrier), quanto na história de uma possível memória coletiva sobre a presença do colonizador francês em países da África. Como Vênus negra, Chocolat se passa em um flashback das lembranças de France, que, intrigantemente, se unem a alguns eventos e cenas do passado em que ela não estava efetivamente presente. Ou seja, sua memória se mescla a uma memória construída posteriormente pela personagem - ao longo de sua vida, após seu retorno à França, por exemplo -, ou, ainda, à memória de um outro personagem que protagoniza, de certa forma, a infância de France, Protée (Isaac de Bankolé), servente da casa, um "boy".

Segundo Claire Denis, o filme foi parcialmente inspirado pelo romance Une vie de boy (1956), do autor camaronês Ferdinand Oyono's, que conta a história de Toundi, que se torna um "boy", mas que se conscientiza, através da relação com os brancos da casa, da arbitrariedade e do poder do colonialismo4. Protée e Toundi possuem muitas semeIhanças, sobretudo na relação com os patrões, já que em alguns momentos rompem com a coisificação e obediência esperadas, tornando-se críticos e reativos. Assim, Protée e France compartilham lembranças desse período na África e, embora o ponto de vista do filme seja dela, um ponto de vista inclusive feminino, da mescla de suas memórias de infância com as imagens construídas na memória até a vida adulta - quando decide revisitar a África, reviver essas memórias, ou mesmo completar suas lacunas -, o olhar de Protée também está presente, especialmente nas cenas em que France não está.

"O Oriente era praticamente uma invenção europeia e fora desde a Antiguidade um lugar de episódios romanescos, seres exóticos, lembranças e paisagens encantadas, experiências extraordinárias" (Said, 2007, p. 27). Essas lembranças, paisagens encantadas, seres exóticos, abrem o filme de Denis. Uma linda praia onde um homem e uma criança são observados. Ele e a criança brincam no mar. Seus corpos negros brilham ao sol. Então, eles saem do campo de visão do espectador e a câmera se volta para o observador, que é uma mulher branca, France. Ela olha o homem negro não com olhos de curiosidade, mas de desejo. Com essas poucas informações a respeito desses personagens, o espectador rapidamente presume que eles são os "seres exóticos", habitantes daquela "paisagem encantada", e que a moça é provavelmente uma turista europeia em busca de "experiências extraordinárias", ou quem sabe, ainda, de um "episódio romanesco". A câmera mostra ainda a criança e o homem deitados na areia escura, sentindo

${ }_{4} \mathrm{O}$ livro Une vie de boy, de Ferdinand Oyono, tornou-se um clássico da literatura africana escrita em Francês. Ele foi escrito a partir das memórias encontradas no diário do jovem Toundi, que descreve os colonos como superficiais e hipócritas. É interessante porque o poder da estrutura do colonialismo é invertido e os brancos funcionam como objeto de curiosidade dos colonizados (Mayne, 2005, p. 35). 
as ondas baterem em seus corpos. Ela, que ainda observa, limpa seu pé branco na areia escura e parte caminhando em direção à estrada.

O homem passa de carro, a vê caminhando na estrada e oferece-lhe uma carona, assim, sabemos que ele é, na verdade, um americano de origem africana, expatriado para a África, e ela, uma francesa que passara a infância e a adolescência nesse continente. Com essa pequena subversão do estereótipo, que surpreende o espectador, Claire Denis faz atentar para certas questões a respeito da alteridade - quem é Outro, para quem se é Outro, o que faz ser Outro.

No carro, através da janela, France continua a observar a paisagem, que começa a se confundir com uma outra paisagem, embora não muito distinta. Nesta outra paisagem que se mescla, vemos uma caminhonete e uma menininha ao lado de um jovem negro. A menininha observa a paisagem. A mesma paisagem. A paisagem do trajeto entre Limbe e Douala (cidades litorâneas dos Camarões). A menina e o rapaz negro olham para direções contrárias, embora a cumplicidade entre eles seja evidente, é como se seus mundos não se misturassem, como se o futuro vislumbrado pelos olhares levasse a caminhos opostos. Estamos, assim, contemplando as lembranças de France.

O desejo de France, e talvez mesmo a necessidade, de voltar à África para reviver essas memórias de sua infância está ligado à busca de sua própria identidade e, sobretudo, à busca de um lugar.

Assim como nenhum de nós está fora ou além da geografia, da mesma forma nenhum de nós está totalmente ausente da luta pela geografia. Essa luta é complexa e interessante porque não se restringe a soldados e canhões, abrangendo também ideias, formas, imagens, representações. (Said, 2007, pp. 39-40)

A volta de France marca a reivindicação pelo seu lugar de infância e de adolescência, um lugar a que pertence e que lhe pertence, mesmo que parcialmente. Ela precisa dele para ser France adulta, porém, a reinvindicação desse lugar traz toda uma gama de lembranças que não se restringem a uma reconstrução dos espaços físicos (a casa, a horta da mãe, a paisagem), mas incluem as memórias afetivas, os sentimentos experienciados nesses espaços. Desse modo, essa luta pelo espaço nunca será individual, pois, se há necessidade de luta, é porque o espaço está sendo disputado, ou seja, há, no mínimo, dois indivíduos reivindicando determinado espaço.

Em Chocolat, essa dualidade de disputa e compartilhamento do espaço se dará, sobretudo, pelos personagens de France e Protée. Do início ao fim do filme, corpos negros e brancos estarão presentes em cena disputando essa geografia. Contudo, se por um lado France precisa diariamente conquistar o espaço em que vive, a natureza, as pessoas do local, por outro - e isso fica bastante evidente na France adulta -, ela se sente como pertencente a um outro lugar. Sente que ali, no Norte dos Camarões, ela está com sua família de passagem. Ao falar de sua infância na África, Claire Denis - em entrevista para Thierry Jousse, em 2002 - descreve o continente como uma terra em que viveu e que ama muito, porém, não como seu lar: 
meu pai era um funcionário colonial, então eu sabia que estava de passagem. Eu não perdi meu país, porque eu sabia que ele nunca havia me pertencido. Nada nos pertencia... Eu pertencia a um país - a França - sobre o qual eu não sabia nada. (citada em Mayne, 2007, pp. 10-11)

Fica evidente, no filme e nas palavras de Denis, que o próprio sistema colonialista não possibilita relações que gerem sentimentos de fraternidade (com os habitantes do local) e de pertencimento (ao local). A base da relação colonial será sempre a dominação e todos os vínculos nela estabelecidos sempre serão de opressão. A dominação colonial dos povos nativos fez parte de um sólido movimento histórico mundial, que atingiu seu apogeu no início do século XX e do qual também fizeram parte o controle científico e estético da natureza - por meio de esquemas classificatórios -, a apropriação capitalista dos recursos e a organização imperialista do planeta sob um regime pan-óptico (Stam \& Shohat, 2006, p. 141). Fica evidente, portanto, que o controle colonial era exercido em todos os campos, não apenas no territorial e econômico, que são, talvez, os mais evidentes, mas não os mais importantes. Na verdade, não há uma hierarquia de importância em relação a essas espécies de controle para o sistema colonial, o importante é o próprio controle, que deve ser exercido sobre todos os aspectos da vida dos nativos.

Segundo Hall, Gramsci estabelece, por exemplo, uma diferença entre uma classe que "domina" e uma classe que "dirige" (Hall, 2003, p. 314). Essa articulação interessa, sobretudo, para compreender o papel do pai de France, Marc Dalens, oficial do distrito e chefe da subdivisão. Dalens é um homem de aparência muito suave, normalmente seu tom de voz é baixo, ele parece se integrar, de alguma maneira, ao local, se o comparamos aos outros europeus que aparecem no filme. Gosta de observar os homens e a natureza e de desenhá-los em um caderno que está sempre consigo. A autoridade de Dalens e seu poder sobre os povos dali estão ligados ao conceito de "direção" desenvolvido por Gramsci e retomado por Hall. Pois,

domínio e coerção podem manter a autoridade de uma classe específica sobre a sociedade. Mas seu "alcance" é limitado. Ela precisa recorrer continuamente aos meios coercitivos, em vez de conquistar apoio. Por essa razão, ela não é capaz de promover a participação positiva dos distintos setores da sociedade em um projeto histórico de transformação do estado ou de renovação da sociedade. A "direção", por outro lado, também possui seu aspecto "coercitivo". Porém ela é "conduzida" pela conquista do consentimento, pela consideração dos interesses dos subordinados, e pela tentativa de se tornar popular. (Hall, 2003, pp. 314-315)

Dalens parece agradar a todos, tanto aos nativos, quanto aos estrangeiros que aparecem nas suas áreas de domínio. Ele não é ingênuo. Reconhece seu papel de dominador e, até mesmo, a insustentabilidade de tal dominação: "um dia vamos ser chutados para fora daqui" (Chocolat, 1998), diz ele. Uma das suas funções na colônia é criar estradas e, analogicamente, essa função é estendida à sua relação com as pessoas. 
É Dalens que estabelece essas "estradas comunicacionais" entre os personagens. Ele medeia quase todas as relações, ou seja, dirige o processo colonial. Consciente do seu deslocamento, Dalens se estabelece facilmente no seu papel de dominante, fazendo de Outro os nativos do Norte dos Camarões em sua própria terra.

Aimée, esposa de Dalens e mãe de France, também não subverte seu papel de esposa de oficial. Embora se sinta claramente deslocada e insatisfeita, ela dá ordens aos empregados, decide a comida, recebe convidados. Como de costume em sua cultura, Aimée descansa após o almoço (faz a siesta) - nesse momento, France aproveita para "escapar" da casa grande. Sai às escondidas pela janela e dirige-se a uma espécie de senzala, onde há homens e mulheres negros ocupados em seus afazeres cotidianos. Uma dessas mulheres se dirige a France: "você não está cochilando? Você verá, você vai ficar preta e seu pai vai gritar!" (Chocolat, 1998). Diante da impossibilidade de levar uma vida francesa - France não frequenta a escola, não tem contato com outras crianças com quem possa brincar -, talvez a menina prefira o movimento constante da senzala ao marasmo do arrastar do tempo na casa grande.

Contudo, e apesar de ser uma criança, France reproduz a autoridade dos pais, a autoridade do dominante no sistema colonial, do qual ela é agente e, também, possivelmente, vítima. A menina dirige-se a Protée de maneira autoritária. Por exemplo, num dos momentos em que France está à mesa, ela exige que Protée experimente seu mingau. Ele se ajoelha e ela começa a alimentá-lo; num primeiro momento, parecendo uma criança mais nova, ou um bebê, mas, ao longo da cena, esse ato vai se assemelhando mais ao de um animal. Ao cair um pouco do mingau na mão de France, Protée lambe, como um cão faminto. Ela ri da atitude dele, porém, ele permanece sério. Sua comunicação com Protée limita-se mais aos gestos, olhares; eles trocam pouquíssimas palavras. Ao mesmo tempo em que parecem possuir uma cumplicidade, há um estranhamento entre dois mundos incapazes de se encontrar em harmonia.

Desde o início do filme, ou seja, antes do flashback, com France adulta, e ao longo de todo o filme, com France criança, ela expressa poucas emoções. Ela quase não sorri, ela mais observa, assiste, do que age de fato, é como se assistisse sua vida à distância, e algo sempre parece lhe escapar. Essa posição vivida por France parece ter relação com seu status de mulher na África, porém, parece igualmente ser fruto da perspectiva de Denis enquanto diretora. Ainda, é necessário atentar para o fato de que as imagens a que o espectador tem acesso são as lembranças de France, que as seleciona em sua memória e que, de certa forma, escolhe quais e como serão revividas.

Além desses personagens, Denis traz para o filme uma gama de estrangeiros que habitam ou estão em trânsito na África. Eles são de origens diferentes, assim como se relacionam de maneira diferente com o continente e seus habitantes. Hansen, um senhor norueguês que vive em condições precárias se comparadas às da família de Dalens, se autodenomina um "soldado de Deus" e quer evangelizar os nativos; um inglês que chega à propriedade durante uma das viagens de Dalens e é recebido por Aimée, que o mima, pedindo ao cozinheiro que faça comida inglesa, e, ao vê-lo de smoking no jantar, troca o vestido e ainda concede-lhe uma dança, embora demonstre certa insatisfação 
em receber visitas na ausência do marido; Segalen, um ex-seminarista que está atravessando a África a pé e trabalha na construção de estradas junto com os nativos; um produtor de café que traz consigo uma mucama negra, alimentando-a como a um animal domesticado, no chão do quarto, e com quem faz sexo.

Com essa multiplicidade de personagens, Claire Denis parece querer dar conta de uma distinção que a própria France faz em sua memória dos diversos "tipos" de colonizador. Com isso, ela separa o pais e o afasta de uma imagem de invasor, de explorador. Contudo, essas pessoas diversas que chegam à casa de Dalens, na verdade, oferecem ao espectador uma perspectiva de vários aspectos do colonizador, quer dizer, é o mesmo colonizador, em certo sentido, com essas múltiplas possíveis facetas inscritas nesses personagens europeus. É interessante que o "olhar" deles sobre a África parece distinto, mas não foge da visão eurocêntrica.

Esses personagens reproduzem os padrões coloniais, o patriarcalismo, o racismo, o sentimento de superioridade das nações europeias. Talvez apenas France criança consiga, em alguns momentos, imaginar-se de uma maneira diferente naquela cultura - ela aprende algumas palavras da língua local com Protée, por exemplo -, mas rapidamente se dá conta do lugar que ocupa e da impossibilidade de um real ajustamento. O pai explica, observando a paisagem com a filha:

quando você olha para as montanhas, além das árvores, onde a terra toca o céu, esse é o horizonte. Quanto mais perto você chega dessa linha, mais distante ela se move. Se você andar em direção a ela, ela se afasta. Ela foge de você. Você vê a linha. Você vê, mas ela não existe. (Chocolat, 1998)

Esse horizonte pode ser a fronteira, invisível aos olhos, ou pode ser o futuro insustentável do sistema colonial. Na entrada da casa de Dalens, está inscrita a seguinte frase: "esta casa é a última casa da terra". Foi escrita por um oficial alemão que havia morado ali, explica Aimée ao visitante inglês. Ela acrescenta que "dizem que este oficial foi enforcado por um dos seus boys" (Chocolat, 1998) e olha para Protée, que abaixa a cabeça. Ironicamente, esse oficial está enterrado num pequeno cemitério nos arredores da casa. France questiona se também será enterrada ali.

France e Protée são dois solitários dentro desse sistema que impede qualquer tipo de afeto entre eles. Há um paradoxo no relacionamento deles, uma espécie de intimidade, porém com muito distanciamento. Por apresentarem algum tipo de contradição em seus papéis de colonizador e nativo, France e Protée guardam algumas semelhanças e, por isso, nas memórias de France, as lembranças de Protée se misturam, evocando uma memória colonial coletiva. Embora os patrões demonstrem possuir muita confiança em Protée, ele é tratado como mais um objeto para o funcionamento do aparato colonial.

Ao rejeitar a investida de Aimée, Protée subverte, ao passo em que denuncia, essa imagem do negro hipersexualizado pelo cinema, do nativo enquanto objeto de posse, do

\footnotetext{
${ }^{5}$ Em entrevista a Mark Reid, em 1996, Claire Denis afirma: "o meu pai estava muito interessado na cultura africana e falava muitas línguas africanas. Politicamente, ele sempre foi a favor da independência africana". Esse homem que descreve a cineasta é muito semelhante ao que representa o personagem Marc Dalens no filme (Reid, 1996, pp. 67-72).
} 
negro exótico enquanto objeto de desejo. Ou seja, Protée deixa aparecer, finalmente, a consciência de sua situação e o desejo de rebelar-se, latentes durante todo o filme. Com isso, Aimée pede a Dalens o afastamento de Protée, que, rejeitado pela família, vinga-se na pequena France. Desse modo, é nesses dois personagens, France e Protée, que ficarão as profundas marcas do colonialismo. Dentro da sala do gerador, France pergunta a Protée se o equipamento queima; ele coloca a própria mão sobre o equipamento, induzindo, com esse gesto, a menina a fazer o mesmo. Ambos se queimam profundamente. France lança para Protée um olhar de dor e incompreensão.

Assim, Protée e France compartilham uma mesma marca, que simboliza mutilação e dor. São as marcas do colonialismo. As linhas das mãos onde, supostamente, está inscrito o futuro são apagadas pela queimadura.

O gesto desafiante de Protée se torna agora um poderoso (ao invés de cansado) comentário não verbal sobre os efeitos da repressão colonial e da tentativa de apagamento de sua cultura, história e memória. A pele superficial queima, apagando todas as linhas de identificação ou marcas, levando as impressões. Com essa ação, Protée torna visível o que a presença colonialista acredita praticar: o apagamento do "Outro". (Hayward, 2002, p. 42)

Portanto, se France retornara aos Camarões em busca de preencher certas lacunas de sua memória e de encontrar um lugar de pertencimento, o que ela encontra, de fato, é uma ausência. Ausência de um lugar, das pessoas desse lugar. À medida em que ela consegue preencher algumas dessas lacunas com a própria memória revisitada, novas frestas são abertas por esse ciclo de apagamento constante empreendido pelo colonialismo. A mão negra de Protée e a mão branca de France, ambas queimadas, marcadas para sempre, representam a conexão entre a história desses corpos, pois, embora o colonialismo busque apagar a memória e a história do local que coloniza, substituindo-as por uma história e cultura do colonizador, os corpos que transitam nessas fronteiras, que estão inseridos no processo (tanto dos dominadores quanto dos dominados), também conterão essas histórias e, neles, elas serão inapagáveis. Quando o americano que dá carona a France afirma, ao ver as mãos da jovem, "não vejo nada em suas mãos, nem passado, nem futuro" (Chocolat, 1998), ele não se dá conta de que aquela marca, aquela ausência, é o passado e o futuro.

\section{CONSIDERAÇÕES FINAIS}

Com isso, percebemos em Chocolat, assim como em Vênus negra, um desejo de recuperar a história por meio da memória, não apenas dos personagens, ou das memórias históricas ou coletivas, mas da memória inscrita nos corpos. Esses corpos representam resistência cultural e desejo de ruptura. O Outro deixa de ser um estereótipo forjado pela história, e reforçado pelo cinema - cujo papel de "contador de histórias da humanidade adequou-se perfeitamente à função de retransmissor das narrativas das nações e dos impérios" (Stam \& Shohat, 2006, p. 144) -, para assumir uma função questionadora da 
própria história, contribuindo para o debate que busca revisitar o colonialismo e suas consequências.

\section{REFERÊNCIAS}

Hall, S. (2003). Da diáspora: identidades e mediações culturais. Belo Horizonte: UFMG.

Hayward, S. (2002). Claire Denis's “Post-colonial” Films and Desiring Bodies. L'Esprit Créateur, 42(3), 39-49. Retirado de http://muse.jhu.edu/article/264865

Kilbourn, R. (2005). Cinema, memory, modernity. The representation of memory from the art film to transnational cinema. Nova lorque/Londres: Routledge.

Marks, L. (2000). The skin of the film. Londres: Duke University Press.

Martin, M. (2013). A linguagem cinematográfica. São Paulo: Editora Brasiliense.

Mayne, J. (2005). Contemporary film directors - Claire Denis. Urbana e Chicago: University of Illinois Press.

Ndiaye, P. (2008). La condition noire. Essai sur une minorité française. Paris: Calmann-Lévy.

Reis, M. (1996). Claire Denis interview. Colonial observations. Jump Cut a review of contemporary media, 40(1), 67-72. Retirado de https://www.ejumpcut.org/archive/onlinessays/JC4ofolder/ClaireDenis/nt.html

Said, E. (2007). Orientalismo - o Oriente como invenção do Ocidente. São Paulo: Companhia das Letras.

Shohat, E. \& Stam, R. (2006). Crítica da imagem eurocêntrica. São Paulo: Cosac Naify.

Žižek, S. (2009). Sobre la violencia - seis reflexiones marginales. Buenos Aires: Paidós.

\section{NOTA BIOGRÁFICA}

Catarina Andrade é Professora do Departamento de Letras/Francês UFPE. Doutora em Comunicação/Cinema (UFPE). Autora do livro As fronteiras da representação: imagens periféricas no cinema francês contemporâneo e co-autora dos livros Cinema, globalização, transculturalidade, filmes da África e da diáspora e Comunicação e interculturalidade. Foi coordenadora e curadora do cineclube da Aliança Francesa Recife (2013-2017). Atua principalmente nos temas: memória, identidade, corpo, pós-colonialismo, interculturalidade, cinema contemporâneo.

Email: cati.andrade@gmail.com

Morada: Rua Sá e Souza, 964, apto 103. Boa Viagem. Recife-PE. Brasil. CEP: 51030-065

\section{* Submetido: 09-09-2018 \\ * Aceite: 09-01-2019}

